\title{
The Academy of Construction and Architecture of the USSR: Formation of the Idea of a New Goal in the Conditions of Transition to "Industrial Rails"
}

\author{
Konstantin Khrupin ${ }^{1, *}$

\begin{abstract}
${ }^{1}$ Scientific Research Institute of the Theory and History of Architecture and Urban Planning, Branch of the Central Institute for Research and Design of the Ministry of Construction and Housing and Communal Services of the Russian Federation, Moscow, Russia

*Corresponding author. E-mail:hkongen@gmail.com
\end{abstract}

\begin{abstract}
The active search for the optimal structural arrangement of the profession itself, as well as the architectural and construction academic science, in particular, which would correspond to the tasks of the epoch, in the Union of Soviet Socialist Republics (USSR) in the middle of the XX century, was largely in line with the contemporary situation when the architectural and construction complex again passed through the "era of changes".
\end{abstract}

That search has not always been successful, the possibilities of the professional reflection were limited in many ways, the goals of architectural and construction activities were often imposed from the outside, and the products of the construction industry became the criterion of the academic activity.

The article considers the formation by an academic science of the idea of its primary result of activity, as an industrial, architectural and construction, and urban-planning product, in the realization of the directive task of the industrialization of the building construction activity.

Keywords: The Academy of Architecture of the USSR, The Academy of Construction and Architecture of the

USSR, science, industrial housing construction, technology

\section{INTRODUCTION}

Standardized industrial housing construction has received a vast scale in the USSR as a way to solve the problem of the housing shortage. The directive impetus was given by the course on the general industrialization of the country in the mid-1920s. According to it, the architectural and construction industry, as well as others, was to switch to "industrial rails". In this process, the state gave a significant role to science, in particular, the academic one. It took quite a long time and was difficult for the Architectural and Construction science of the USSR to take this path.

In the first half of the 1950s, the political leader in the USSR has changed. Cardinal transformations in the social and scientific-technical sphere took place. The process of "industrialization" of architectural and construction science has been sharply activated. The

*Fund: This paper was funded by the Program of Fundamental Researches of the Ministry of Construction, Housing and Utilities of the Russian Federation and the Russian Academy of Architecture and Construction Sciences 2020, the Research Project 1.7.1 long-overdue changes in the architectural and construction activity started to be realized to a greater or lesser extent. First of all, they concerned the general orientation to the standardization of the design and industrial methods of construction as well as the creation of a new scientific center.

In the Soviet construction, the course on industrial housing construction was formed at the end of the 1930s and has been developed during the period of the reconstruction in the second half of the 1940s. This course was approve in a directive manner by N. S. Khrushchev at All-Union meeting on the construction development in 1954 [1]. He relied exclusively on the use of pre-cast concrete, with alternatives virtually excluded, and this fact determined the direction of the efforts of architects, constructors, engineers, and scientists for many years to come.

\section{THE UNDERSTANDING OF THE GOAL}

At the general meeting of the Academy in 1956, the Vice-President of the Academy of Construction and Architecture of the USSR (ACA), architect A.V. 
Vlasov, formulated the purpose of the academic science in terms of the state guidelines. The Academy should have made every kind of effort "to present the models of structures in their construction as magnificent, as they have seen at the air parade, where the comrades Yakovlev, Sukhoi, Lavochkin, and others showed excellent models of machines", and in order to achieve it, in his opinion, "it was necessary to organize the creation of standardized buildings and structures in a new way so that they could give authentic models of completed structures that have been perfected both architecturally and constructively" [2].

In this judgment, which is not devoid of pathos, we can distinguish the following aspects: the task of the ACA was to create finished models of buildings ready for mass replication, to adopt the mechanical engineering technology, to organize its activities in accordance with the tasks set.

In the mid-1950s, the Academy's research and design work brought to the fore the development of a full-fledged set of scientific, design, organizational, and technological measures that would dramatically increase the volume of housing construction. The main priority was the social task of providing each family with a separate apartment. The economic aspect there was a reduction of the cost of a separate apartment to the average cost of a room in a communal apartment. Together, this meant adjusting the existing regulatory and technological framework, clarification of the typology of buildings and structures, development of a set of questions related to small-size apartments, multistory construction, the use of modern building materials and structures, large-panel ones in particular.

\section{PREREQUISITES FOR THE NEW GOAL}

The ACA did not start from scratch. The Academy of Architecture of the USSR (AA) has accumulated experience in a standardized design, which presented certain solutions to functional, structural, technological, economic, urban planning, and aesthetic issues, as well as developed and partially tested structural schemes that met the requirements of the industrialization of the housing construction.

The tasks set for AA after its reorganization in 1939 also concerned the development and implementation of the principles of typification and standardization in the practice of construction, speeding up its pace and reducing the cost [3]. At the same time, the Academy in its scientific and practical activities faced the need to combine the problems associated with the industrialization of construction and conducting a course on the mastering of the classical heritage, a task initially set for it when it was created in 1934 and implemented through the training of highly qualified personnel of architects.
The increase in the technical level of construction and its volume in the second half of the 1930s caused the Academy to worry that the creation of an "architectural organism" in practice has been reduced only to the solution of technological issues, while it was "not just an object for consumption that met certain needs", but a complex (holistic) process, the result of which was "an integral (and complex) product", in which, in addition to the technical component, there was also an ideological one, which "created its own "audience" both in the sense of aesthetics, as well as in the sense of educating and re-educating the aesthetic consciousness of society" [4]. These concerns arose in connection with the solution of the problem of mass housing construction, which resulted in a contradiction between the use of new construction technologies and the creation of an artistic image of an apartment building.

The search was conducted in the direction of finding artistic and compositional techniques that would have met the principles of standardized design while addressing the issues of standardization, the unification of decorative and structural elements.

In practice, there was a situation when the underdevelopment of the construction industry, the lack of a full-fledged regulatory framework, coordinating bodies in the architectural and construction industry compromised the quality of standardized design and went against government directives aimed at reducing the cost of construction and increasing its volume.

Thus, to reduce the cost of and ensure mass housing construction, new construction technology in the form of the rapid-flow method was proposed. It was developed and recommended for the practical use by the architect A. G. Mordvinov, in 1938, and in 1939 he became one of the Vice-presidents of AA, which was believed to contribute to the implementation of the tasks of typification and industrialization.

For the first time, he tested this proposal on the construction of Bolshaya Kaluzhskaya street in Moscow. Standardized houses have been designed, considering the use of industrial construction elements in them, and in general, the organization of construction work was subordinated to the conveyor principle, which was the main idea of the Mordvinov method.

During the development of this project, one significant feature of the standardized housing construction has been revealed. Initially, the developed model project has supposed to be used apiece in each district of Moscow, but after the client has changed the project requirements, this project has to be used within a single street. As a result, the authors faced the issue that the street facade turned out to be monotonous and repetitive and did not meet the artistic level of the main street. The project was urgently revised. 
Despite the fact that some parts were manufactured at the factory, the ones delivered to the construction site were often of poor quality, which eventually led to their completion and reworks at the construction site. The level of construction itself was not high. Due to the significant variety of constructive and decorative elements, there was no substantial reduction of the construction time.

Architects A. K. Burov and B. N. Blokhin have faced similar problems when developing the project for the construction of large-size elements buildings. In their experimental projects, they raised a whole range of questions, including the large blocks manufacturing technology, the method of their installation, and the role of aesthetics in the industrial housing construction. The first large-block buildings have been built in Moscow on the Velozavodskaya, Valovaya, Bolshaya Polyanka, Berezhkovskaya embankment streets at the end of the 1930s. In these buildings, the authors considered prefabricated industrial housing construction only as a way of erecting a building.

However, the developed methods did not provide the necessary economic effect. The construction of buildings using traditional building materials and techniques was cheaper than construction designed for industrial products and methods.

The process of solving the problems of real-world construction formed the idea in AA that the desired effect of industrialization can be achieved through the reduction of the variety and increase of the repeatability of the standard elements used. At the same time, they must have been interchangeable and manufactured within minimum tolerances, which would ensure their quick and high-quality installation. Factory production met these requirements. It also set another equally important requirement - the stability of the standard, at least for 2-3 years. Otherwise, the industry would have no time to adapt.

In the early 1940s, the Institute of mass structures of AA conducted research on housing and came to the conclusion that it was possible to successfully resolve the issues of mass housing construction if focusing on the following areas: differentiation of the city's development areas; construction of four-, five-story buildings within the city area and two-story buildings in the countryside; the transition to the type of a smallsized individual apartment; revising the design standards; development of the modular design system as the basis of the standardization of building elements [5]. In fact, they already identified the main range of issues that would have been solved by the ACA, and in the early 1940s, but neither the technical conditions of production nor the possibilities for solving social problems have been developed for that purpose.
As a result, the Academy was searching for adequate architectural and compositional techniques and design schemes in the conditions of standardized design and emerging industrial construction technology. They continued in the second half of the 1940s when one of the main directions was the development of problems related to large-element, mass, low-cost construction.

In the late 1940s, AA has managed to realize the country's first frameless multi-story large-panel house. It has been developed by the Research Institute of Architecture of Mass Structures and the Research Institute for Construction Equipment and implemented in Magnitogorsk in 1949 [6]. The choice of the location was not accidental, as there has already been an established industrial production base, which, after improvements, allowed for construction. Several experimental buildings have been built in a short time.

This experimental construction proved to be an important experience for the large-panel area, indicating the pros and cons, both in terms of architecture and construction.

On the one hand, it demonstrated the speed of construction and the reduction of its cost due to the use of large industrial parts. In the technological aspect, this experience was useful in the construction of the Magnitogorsk factory of prefabricated housing construction, which has started in 1953. On the other hand, with the construction of houses of the same type, the architects have faced the issue of the street facade again, as in the 1930s, with the need to overcome its monotony, since the structural scheme of the building largely predetermined the architectural composition of the facade. The facades of the buildings have been designed according to the classical canons. The applied decorative elements simultaneously solved the problems of panel joints - the "fundamental" issue of a large-panel house. The adopted frameless structural scheme also influenced the layouts of the apartments and the compositional capabilities of the facades, clearly setting the limits within which the architects should have worked.

By the early 1950s, the level of the construction industry has grown significantly, which allowed expanding design commissions. The directions of transition from traditional forms and methods of building construction to prefabricated industrial housing development have been outlined.

The perception of a standardized house has gradually changed. In 1944 A. Arkin, a corresponding member of AA, wrote: "mass construction and industrialization break the idea of the uniqueness of the house that architects are used to" [7]. At the same time, the house has not only become a product of mass production. It became "an element of the array, the part 
of the housing". In contrast to the production of machines that produce goods as individual units, different types of dwellings create a new synthesizing quality, an organic combination of these types - the diversity of mass residential development, Arkin believed [7].

The laws of industrial production required the reduction of the amount of both structural and decorative elements used in a standardized project. They influenced the artistic side of the entire building, simplifying its spatial structure, the configuration of its plan, and the composition of the facades. AA in the second half of the 1940s noted that the natural desire for "technical simplicity had become an obsession with technical primitivism, $\langle\ldots\rangle$ constraining the normal free arrangement of the apartment layout" [8] and believed that the plan of a typical residential section and house should have been flexible, maneuverable and architecturally potent, and the variety of architectural and planning solutions should not have contradicted the creation of a limited range of standard factory parts. As a means of increasing the artistic expression of the house, it was suggested to strive to expand the size and variety of the section configurations. The use of compositional accents in the form of entrances, stairwells, bay windows, balconies-elements inherent in "big architecture" could enhance the effect. All the above mentioned combined gave plasticity and expressiveness to the volume of the building. These techniques would have been remembered in the search for ways to overcome the facelessness of panel housing in the early 1960 s.

At the same time, the Academy had a clear understanding that the methods of serial design of houses suited for the industrial method of production of parts and construction itself were close to the methods of the design of any serial factory products. The term "the model of the house" became as familiar as "the model of the airplane". Thus, it followed that such a "model" of the house should have passed such a stage as "testing" since when it is accepted for production, the technological process should be organized for a sufficiently long period. It is no accident that AA was supposed to create a special unit for the experimental design and construction [3].

Gradually adjusting their activities to the construction technology, the Academy began to come to the conclusion that when designing a residential building with an complicated configuration of the plan, the architect must strive to form it from the sections of a simple rectangular shape and provide dedicated connecting parts (balconies, passages, etc.), when making an angular connection.

In the early $1950 \mathrm{~s}$, the Academy even more inclined to believe that houses should be simple in plan, and urban planning techniques can help achieve the necessary diversity. This idea was significantly influenced by a number of internal and external factors, which eventually led to the transition to a different organizational form of the Academy in the mid-1950s [3], [9].

\section{THE REALIZATION OF THE GOAL}

The ACA continued to improve standardized projects based on new state guidelines and began to participate in the development of industrial building construction technology. The identified archival and published materials related to the scientific and practical activities of the ACA showed a considerable volume and range of solved urban planning, architectural, engineering, and construction tasks.

It is difficult, and often impossible, to standardize the space of human activity. In fact, the ACA tried to solve this problem by searching for a common denominator for industrial technology and architectural and construction activities that would provide it with the practical result expected by industry leaders.

While in the first years, the ACA has raised a question of what to take as a basis for the typification, later, after the next resolutions, as well as experiments in practice, it became clear that the most economical and fast way was to create a type of a house wholly manufactured at the factory, despite the fact that before the predecessor of the Academy was orientated by the "from a standard item to a project" principle.

After the all-Union competition of 1956 and a pilot test, the choice was made for the 1-464 series with often located load-bearing transverse walls and a roomsized reinforced concrete floor, as the most optimal option. It was functionally resolved and fit in with the industrial technology.

Later, the 1-467 and 1-468 series appeared with sparse located load-bearing transverse walls. They made it possible to implement a flexible layout of apartments to address demographic issues, as well as to unify the structural elements of residential and public buildings.

Basing on these series, the ACA institutes began to develop complex series that include both residential and public buildings. They contained a broader and more developed nomenclature of building types by purpose, length, number of floors, and variety of apartment types.

The most optimal and promising series was considered to be 1-468A. On its basis hotel-type houses, "tower houses": nine-storey, and later twelvestorey were developed; a kindergarten-nursery, a school, a primary service block, public and shopping centers of neighborhoods were also included in this series. 
The development of residential areas in the conditions of industrial production was organized in the form of a continuous flow, based on a uniform character of technology, while it became mandatory to unify all prefabricated elements of residential and public buildings.

The appropriate organizational structure and personnel were formed for such tasks in the ACA, trying to take into account the "shortcomings" inherent in AA. So, for example, N. V. Bekhtin, a technology engineer, became president [10]

\section{CONCLUSION}

The ACA was fully involved in the activities that are subject to the technology of industrial housing construction, which has become predominant in mass housing construction. Standardized houses that were assembled entirely from prefabricated elements became very similar to any other industrial product, and the creation of house-building plants in the late 1950s confirmed this. The first such plants were created in Leningrad, and in the early 1960s, they appeared in Moscow. These factories began to produce a finished product - the house. This trend continued in the following years. As a result, a standardized house turned from a construction object into a product of industrial production.

It can be argued that the aspects laid down in Vlasov's thesis were generally realized, forming a new goal of academic architecture and construction science.

As a result, the main methodological problem of The ACA has become the organization of its scientific and practical work in such a way to find the necessary mechanisms and approaches to eventually create a finished modern architectural and construction urban development product.

The criterion for the effectiveness of academic activities was the modern architectural and construction urban development product - a product of mass construction, which took into account the specified specific parameters obtained as a result of the selection and improvement of architectural and planning, design, and engineering solutions embedded in new technologies, and economic justification.

\section{References}

[1] All-Union Meeting of Builders, Architects, and Workers of the Building Materials Industry, Construction and Road Engineering, Design and Research Organizations (Vsesoiuznoe Soveshchanie Stroitelei, Arkhitektorov I Rabotnikov Promyshlennosti Stroitelnykh Materialov, Stroitelnogo I Dorozhnogo Mashinostroeniia, Proektnykh I NauchnoIssledovatelskikh Organizatsiy). Moscow, 1955 [in Russian].
[2] A. V. Vlasov, The Speech at the General Meeting of Full Members of the Academy of Construction and Architecture of the USSR on June 27, 1956 (Vystuplenie A. V. Vlasova Na Obshchem Sobraniia Deistvitelnykh Chlenov Akademii Stroitelstva I Arkhitektury SSSR 27 iiunia 1956 goda). Russian State Archive of Economics. Archive fund 293, Inventory 5, case file 1, p. 67 [in Russian].

[3] K. Khrupin, Transformation of Architecture and Construction Science in the Second Half of the 1940s (Transformatsiia Arkhitekturno-Stroitelnoi Nauki Vo Vtoroi Polovine 1940-H Godov). Architecture and Modern Information Technologies, 2015, No 4(33), pp. 47-56. Access URL https://marhi.ru/AMIT/2015/4kvart15/hrupyn/abstract.php, pp. 3, 9 [in Russian].

[4] I. Matsa, Architecture and Technology (Arkhitektura i Tekhnika). Architecture of the USSR, No 3, 1936, p.7 [in Russian].

[5] The Academy of Architecture of the USSR (Akademiya Arkhitektury SSSR). Moscow, 1944, p. 32 [in Russian].

[6] Z. Nesterova, Large-Panel Construction in Magnitogorsk (Krupnopanelnoe Stroitelstvo V Magnitogorske). Soviet Architecture, No 8, 1957, pp. 42-50 [in Russian].

[7] A. Arkin, The Architecture of the City and Typification of Housing (Arkhitektura Goroda I Tipizatsiia Zhilishcha). Architecture of the USSR, No 8, 1944, pp. 17-23 [in Russian].

[8] A. Zaltsman, The Main Architectural Issues of Mass Housing (Osnovnye Arkhitekturnye Problemy Massovogo Zhilishcha). Materials of the VII session of the Academy of Architecture of the USSR, 1947, p.117 [in Russian].

[9] K. Khrupin, The Academy of Architecture of the USSR: Attempts at Reorganization and the Task of Engineering and Construction Sciences Integration (Akademiia Arkhitektury SSSR: Popytki Reorganizatsii I Zadacha Integratsii InzhenernoStroitelnykh Nauk). Architecture and Modern Information Technologies, 2019, No 4(49), pp. 47-56. URL: https://marhi.ru/AMIT/2019/4kvart19/PDF/03_khrupin.pdf [in Russian]

[10] K. Khrupin, The Academy of Construction and Architecture of the USSR in 1955-1963s (Akademiya Stroitelstva I Arkhitektury SSSR 1955-1963s), Architecture and Construction in Russia, No 8, 2010, pp. 30-37 [in Russian]. 